\title{
市販静注用脂肪乳剂の安定性*1
}

新井克明, 堀内 学, 荻野雅資, 佐藤信一, 吉野清高, 町島 啓
筑波大学附属病院薬風部*2

\section{Stability of Fat Emulsions for Intravenous Use in the Market*1}

\author{
KATSUAKI ARAI, MANABU HORIUCHI, MASASHI OGINO, \\ SHINICHI SATO, KIYOTAKa Yoshino, HIRAKU MACHISHIMA \\ Department of Pharmacy, University of Tsukuba Hospital*2
}

(Received December 13, 1983)

\begin{abstract}
Four kinds of fat emulsions for intravenous injection in the market were preserved under the following three conditions: at $7^{\circ}, 20^{\circ}$ and $30^{\circ} \mathrm{C}$ in light-resistant containers. Under these conditions the time-course changes in a particle shape, $\mathrm{pH}$, peroxide and free fatty acid were studied for 6 months. No time-course changes in the particle shape were observed in all of 4 products at the 3 different temperatures while $\mathrm{pH}$ value was decreased slightly with time at $30^{\circ} \mathrm{C}$. No significant difference was observed in peroxide at any of the temperatures, but free fatty acid concentration was apparently increased at $30^{\circ} \mathrm{C}$. From these results, it seems that fat emulsions for intravenous injection is recommended to be kept in a cold place.
\end{abstract}

Keywords_f fat emulsion; stability; time-course change; temperature; peroxide; free fatty acid

はじめに

現在, わが国で市販されている静注用脂肪乳剤は, 表 1に示すように大豆油を大豆リン脂質で乳化した製品 $\mathrm{A}$ と，大豆油を卵黄リン脂質で乳化した製品 $\mathrm{B}, \mathrm{C}, \mathrm{D}$ の 4 種類である. 一般に脂肪乳剤は低温に保存すれば長期 間安定であり，粒子の粗大化などが見られないことが報 告されているが, 1)これら 4 製品の保存温度などの貯法 条件が，その組成が類似しているにるかかわらず異なっ ている.そこで今回，これら製㶡の眝法の違いが薬品の 品質にどのような影響をるたらすかについて, 種々の保 存条件下で経時的に安定性を検討した。

\section{站 験 方 法}

市販静注用脂肪乳風 4 種 (A, B , C , D ) を, $7^{\circ} \mathrm{C}$ し 中光, $20^{\circ} \mathrm{C}$ し中光, $30^{\circ} \mathrm{C}$ しゃ光の 3 条件下に保存し,

*1 日本病院薬剤師会関東ブロック第12回学術大会(茨 城, 1982年 8 月）で発表.

*2 茨城県新治郡桜村天久保 2 丁目1-1 ; 1-1, Amakubo 2-chome, Sakura-mura, Niihari-gun, Ibaraki, 305 Japan
それぞれ(1)粒子形成，(2)pH，(3)過酸化物，(4)遊離脂肪酸 の 4 項目について 1 カ月ごとに 6 カ月間検討を行った。 規格範囲は B 社社内規格を用い, $\mathrm{pH}$ は 6.5 8.5, 過酸 化物は $0.5 \mathrm{mEq} / \ell$ 以下, 遊離脂肪酸は $2.0 \mathrm{mEq} / \ell$ 以下 とした.なお，試料とした製品はいずれる製造後 6 力月 以内のものである.

\section{1. 粒子形状}

試料 $0.05 \mathrm{ml}$ を墨汁 $5 \mathrm{ml}$ に気泡をつくらないよう.に 混合し，スライドグラスに混合液を，別のスライドグ スには対照として墨汁のみを載せ，カバーグラスで薄層 塗抹標本を作り自然乾燥して1500倍で鏡検を行った。結 果は実測値を 100 個数えたものとして補正した数値で示 した。

\section{2. $\mathbf{p H}$}

試料約 $20 \mathrm{ml}$ をとり, 第十改正日本薬局方に定める $\mathrm{pH}$ 測定法に従い測定した。

\section{3. 過既化物}

試料 $4 \mathrm{ml}$ を正確にとり, 氷酢酸・クロロホルム混液 (3:2) $30 \mathrm{ml}$ を加え, 静かに振りまぜて溶解させる. 飽 和ヨウ化カリウム溶液 $1 \mathrm{ml}$ を加え, 正確に 1 分間振り 混ぜる. 次に水 $30 \mathrm{ml}$ を加え, はげしく振り混ぜ, さら 
にデンプン試液 $1 \mathrm{ml}$ を加えはげしく振り混ぜながら 青色が脱色するまで $0.01 \mathrm{~N}$ チ才硫酸ナトリウムで滴定 した. 別に水 $4 \mathrm{ml}$ を用い同様に操作して空試験を行っ た. 試験は, 炭酸ガスを通じて溶媒内および器内の空気 を置換して実施した。

\section{4. 遊離脂助酸2)}

試料 $1 \mathrm{ml}$ を正確にとり，1N 硫酸・イソプロパノール ・n-ヘプタン混液 $(1: 40: 10) 5 \mathrm{ml}$ を加えて 1 分間振 り混ぜる. 10分間放置後, $\mathrm{n}$-ヘプタン $3 \mathrm{ml}$ と水 $3 \mathrm{ml}$ を 加兄, 上く混合し, 15分間静置したのち上層の $3 \mathrm{ml}$ を とり,ナイルブルー溶液 $1 \mathrm{ml}$ を加え, 窒素ガスを通し ながら $0.018 \mathrm{~N}$ 水酸化ナトリウム溶液で滴定した．標準 線を作成して, 滴定液の消費量から遊離脂肪酸当量を求 めた.

表 1. 添付文書による各試料の比較

\begin{tabular}{|c|c|c|c|c|c|c|}
\hline \multirow{2}{*}{ 試料 } & \multicolumn{3}{|c|}{ 組 成 $(\mathrm{W} / \mathrm{V} \%)$} & \multirow{2}{*}{$\mathrm{pH}$} & \multirow{2}{*}{ 貯 法 } & \multirow{2}{*}{ 有 効 期 間 } \\
\hline & 脂 肪 & 乳 化 棛 & 等張化剂 & & & \\
\hline A & $\begin{array}{c}\text { 夕゙イ ズ 油 } \\
(10.0)\end{array}$ & $\begin{array}{c}\text { 精製 } \\
\text { ダイズレシチン } \\
\text { (1.2) }\end{array}$ & $\begin{array}{c}\text { 濃グリ.セリン } \\
(2.5)\end{array}$ & $7.0 \sim 8.0$ & $\begin{array}{c}2 \sim 8{ }^{\circ} \mathrm{C} \\
\text { 冷 所 保 存 }\end{array}$ & 18カ月 \\
\hline B & $\begin{array}{c}\text { ダイス 油 } \\
(10.0)\end{array}$ & $\begin{array}{c}\text { 精製 } \\
\text { 卵黄レシチン } \\
(1.2)\end{array}$ & $\begin{array}{c}\text { 注射用 } \\
\text { グリセリン } \\
(2.5)\end{array}$ & $7.8 \pm 0.5$ & $\begin{array}{c}\text { しゃ光 } \\
25^{\circ} \mathrm{C} \text { 以下 } \\
\text { 禁 凍 結 }\end{array}$ & $\begin{array}{c}18 \text { 月 } \\
\text { 瓶ラベルに記載 }\end{array}$ \\
\hline $\mathrm{C}$ & $\begin{array}{c}\text { ダイズ 油 } \\
(10.0)\end{array}$ & $\begin{array}{c}\text { 卵黄 } \\
\text { リ ン 脂 質 } \\
\text { リ1.2) }\end{array}$ & $\begin{array}{c}\text { 濃グリゼリン } \\
(2.5)\end{array}$ & $6.5 \sim 8.0$ & $\begin{array}{l}\text { 冷暗所 }\left(\sim 15^{\circ} \mathrm{C}\right) \\
\text { (現在:は室温) } \\
\text { 禁 凍 結 }\end{array}$ & $\begin{array}{l}\text { 瓶ラベル表示の使 } \\
\text { 用期限内に使用 }\end{array}$ \\
\hline $\mathrm{D}$ & $\begin{array}{c}\text { ダ ズ 油 } \\
(10.0)\end{array}$ & $\begin{array}{c}\text { 精製 } \\
\text { 卵黄レシチン } \\
\qquad(1.2)\end{array}$ & $\begin{array}{c}\text { 注射用 } \\
\text { グリセリン } \\
(2.5)\end{array}$ & $6.5 \sim 8.5$ & $\begin{array}{l}2 \sim 8{ }^{\circ} \mathrm{C} \\
\text { 暗 所 }\end{array}$ & $\begin{array}{l}18 \text { 月 } \\
\text { 瓶ラベル表示の使 } \\
\text { 用期限内に使用 }\end{array}$ \\
\hline
\end{tabular}

表 2. 各保存条件における粒子径の変化

（数字は粒子 100 個中の個数）

\begin{tabular}{|c|c|c|c|c|c|c|c|c|c|c|c|c|c|c|c|}
\hline \multirow{2}{*}{\multicolumn{2}{|c|}{ 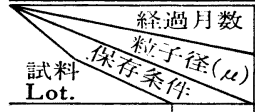 }} & \multirow{2}{*}{\begin{tabular}{c|c|}
\multicolumn{1}{c}{ 開 } \\
$1 \sim 2$ \\
\end{tabular}} & \multirow{2}{*}{ 始 } & \multicolumn{2}{|c|}{1 力月 } & \multicolumn{2}{|c|}{2 力月 } & \multicolumn{2}{|c|}{3 力月 } & \multicolumn{2}{|c|}{4 力月 } & \multicolumn{2}{|c|}{5 力月 } & \multicolumn{2}{|c|}{6 力月 } \\
\hline & & & & $1 \sim 2$ & $2<$ & $1 \sim 2$ & $2<$ & $1 \sim 2$ & $2<$ & $1 \sim 2$ & $2<$ & $1 \sim 2$ & $2<$ & $1 \sim 2$ & $2<$ \\
\hline \multirow{3}{*}{$\begin{array}{l}A \quad \text { 社 } \\
G F 30 A 3\end{array}$} & $7^{\circ}$ & \multirow{3}{*}{0} & \multirow{3}{*}{0} & 0 & 0 & 0 & 0 & 0 & 0 & 0 & 0 & 0 & 0 & 0 & 0 \\
\hline & $20^{\circ}$ & & & 0 & 0 & 0 & 0 & 0 & 0 & 0 & 0 & 0 & 0 & 0 & 0 \\
\hline & $30^{\circ}$ & & & 0 & 0 & 0 & 0 & 0 & 0 & 0 & 0 & 0 & 0 & 0 & 0 \\
\hline \multirow{3}{*}{$\begin{array}{l}B \quad \text { 社 } \\
015 \mathrm{GE}\end{array}$} & $7^{\circ}$ & \multirow{3}{*}{0} & \multirow{3}{*}{0} & 0 & 0 & 0 & 0 & 5 & 0 & 1 & 0 & 2 & 0 & 1 & 0 \\
\hline & $20^{\circ}$ & & & 0 & 0 & 0 & 0 & 6 & 1 & 3 & 0 & 1 & 0 & 1 & 0 \\
\hline & $30^{\circ}$ & & & 0 & 0 & 0 & 0 & 3 & 0 & 1 & 0 & 1 & 0 & 1 & 0 \\
\hline \multirow{3}{*}{$\begin{array}{l}C \quad \text { 社 } \\
0249\end{array}$} & $7^{\circ}$ & \multirow{3}{*}{1} & \multirow{3}{*}{0} & 1 & 0 & 0 & 0 & 0 & 0 & 2 & 0 & 1 & 0 & 2 & 0 \\
\hline & $20^{\circ}$ & & & 0 & 0 & 0 & 0 & 3 & 0 & 1 & 0 & 2 & 0 & 1 & 0 \\
\hline & $30^{\circ}$ & & & 1 & 0 & 2 & 0 & 2 & 0 & 0 & 0 & 2 & 0 & 2 & 0 \\
\hline \multirow{3}{*}{$\begin{array}{lr}\text { D } & \text { 社 } \\
1910352\end{array}$} & $7^{\circ}$ & \multirow{3}{*}{1} & \multirow{3}{*}{0} & 1 & 0 & 0 & 0 & 5 & 0 & 1 & 0 & 2 & 0 & 4 & 0 \\
\hline & $20^{\circ}$ & & & 0 & 0 & 0 & 0 & 5 & 0 & 1 & 0 & 2 & 0 & 1 & 0 \\
\hline & $30^{\circ}$ & & & 1 & 0 & 1 & 0 & 5 & 0 & 4 & 0 & 3 & 0 & 2 & 0 \\
\hline
\end{tabular}




\section{結}

\section{是}

\section{1. 粒子形状}

表 2 亿, 試料 4 種の各保存条件に就ける粒子径の変化 を示した. 試料 Aは，試験開始時においてすへてての粒子 が $0.5 \mu$ 以下であり粒子形状も均一であった．また， 6 カ月後においてもいずれの条件下でも変化はみられなか った．試料Bは， 2 カ月目までは $1 \mu$ 以上の粒子はみら れなかったが， 3 カ月目以後は $1 \mu$ 以上の粒子が観察さ れた. しかし，温度によるとみられる影響はなかった。 試料 $\mathrm{C}, \mathrm{D}$ は, 試験開始時ですでに $1 \sim 2 \mu$ の粒子がみ られたが，経時的には脂肪粒子の合一による大型化や， 保存条件による影響はみられなかった。

\section{2. $\mathrm{pH}$ ，過酸化物，遊離眝助酸}

因 1 亿試料 $\mathrm{A}$ の各試験結果を示した。 $\mathrm{pH}$ はいずれの 条件においても7.2 7.8 の範囲内にあり, 温度による 影響はわずかであった．過酸化物は, $7^{\circ} \mathrm{C}$ の試料で 4 カ 月目に規格範囲を超えたが，他の保存条件ではいずれる 規格範囲内であった．遊離脂肪酸は $30^{\circ} \mathrm{C}$ で若干增加傾 向がみられたが, $7^{\circ} \mathrm{C}, 20^{\circ} \mathrm{C}$ では増加はみられなかっ た。

図 2 亿試料 Bの各試験結果を示した. $\mathrm{pH}$ は $7^{\circ} \mathrm{C}, 30^{\circ}$ $\mathrm{C}$ で 1 カ月目, $20^{\circ} \mathrm{C}$ で 2 カ月目から規格範囲以下と

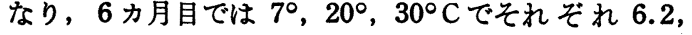
6.0, 5.4 となり, 保存温度が高くなるに従って $\mathrm{pH}$ の低 下が大きく，保存条件の影響を強く受けた。過酸化物は $20^{\circ} \mathrm{C}, 30^{\circ} \mathrm{C}$ では 3 力月目, $7^{\circ} \mathrm{C}$ では 4 力月目より規格 範囲を超え， 6 カ月目にはいずれる約 $0.7 \mathrm{mEq} / \ell$ とな った.このように, 過酸化物の経時変化は大きく, 保存 温度にほとんど無関係酒上上昇がみられた。遊離脂肪酸は $7^{\circ} \mathrm{C}, 20^{\circ} \mathrm{C}$ と保存温度が高くなるに従ってわずか比上 昇し， $30^{\circ} \mathrm{C}$ では 3 カ月目で $2.19 \mathrm{mEq} / \ell ， 6$ カ月目で $4.45 \mathrm{mEq} / \ell$ となり, 3 カ月目以降急激に增加した.

図3飞試料Cの各試験結果を示した. pHは 6.8〜7.6 の範囲にあり，温度による影響はほとんど認められなか った．過酸化物も温度による影響はみられず，いずれの 条件下でる $0.05 \sim 0.19 \mathrm{mEq} / \ell$ と, 他の 3 試料比べ非 常に小さな值を示した．遊離脂肪酸は，保存条件に関係 なく全体的に高い值を示し, $7^{\circ} \mathrm{C}, 20^{\circ} \mathrm{C}$ では変化はほ とんどみられなかったが， $30^{\circ} \mathrm{C}$ では 2 カ月目で規格範 囲を超光，6力月目では $3.45 \mathrm{mEq} / \ell$ となった.

図 4 亿試料Dの各試験結果を示した. 試料Dは試料 C の経時変化とよく似た結果となった. 各保存条件で, $\mathrm{pH}$ は 6.9 7.8 の範囲にあり温度による影響はわずかで あった. 過酸化物は $0.1 \sim 0.4 \mathrm{mEq} / \ell$ の範囲にあり, 温度による影響はみられなかった。遊離脂肪酸は $7^{\circ} \mathrm{C}$,

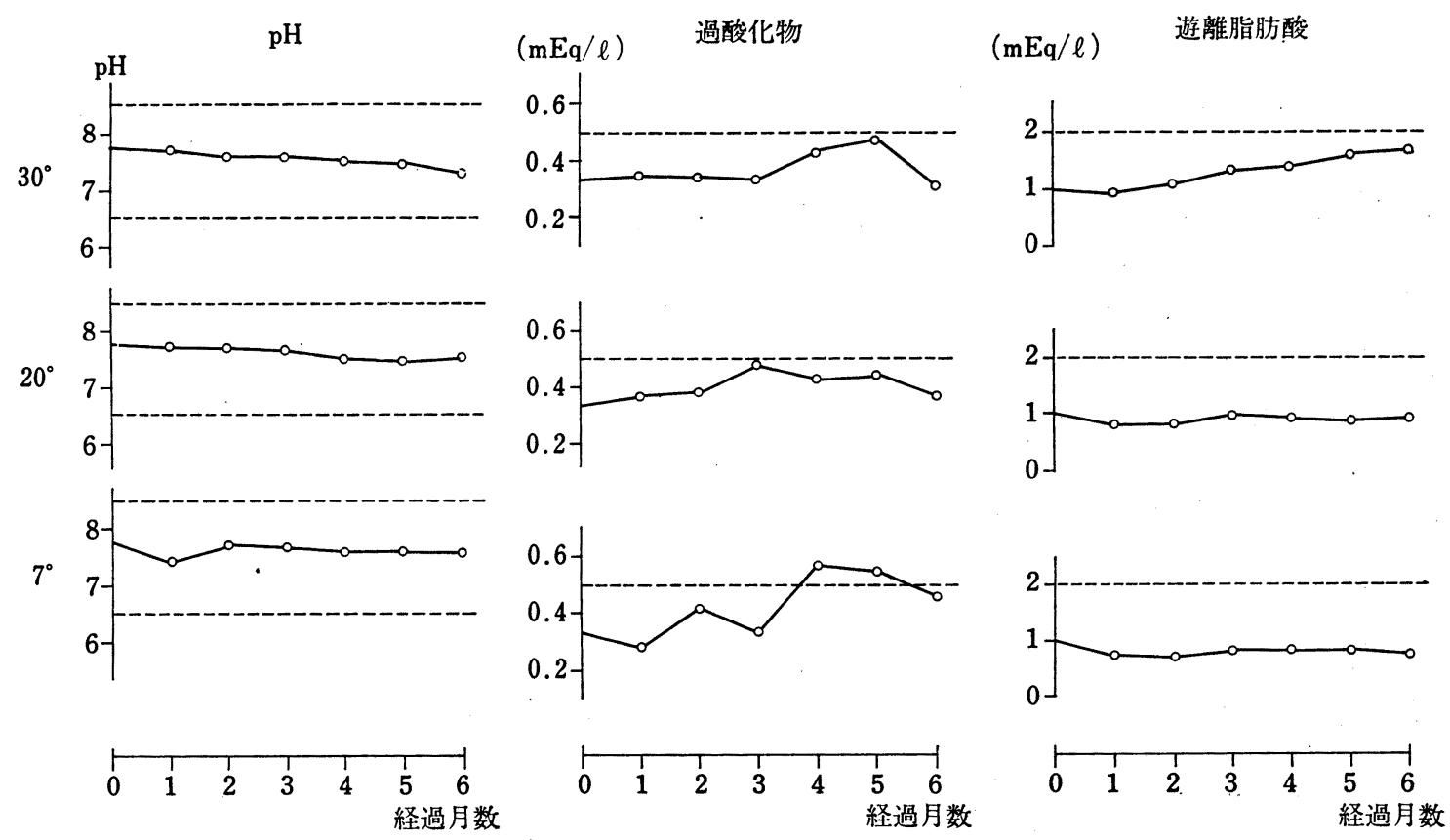

図 1. 各保存条件における試料 $\mathrm{A}$ の試験結果 

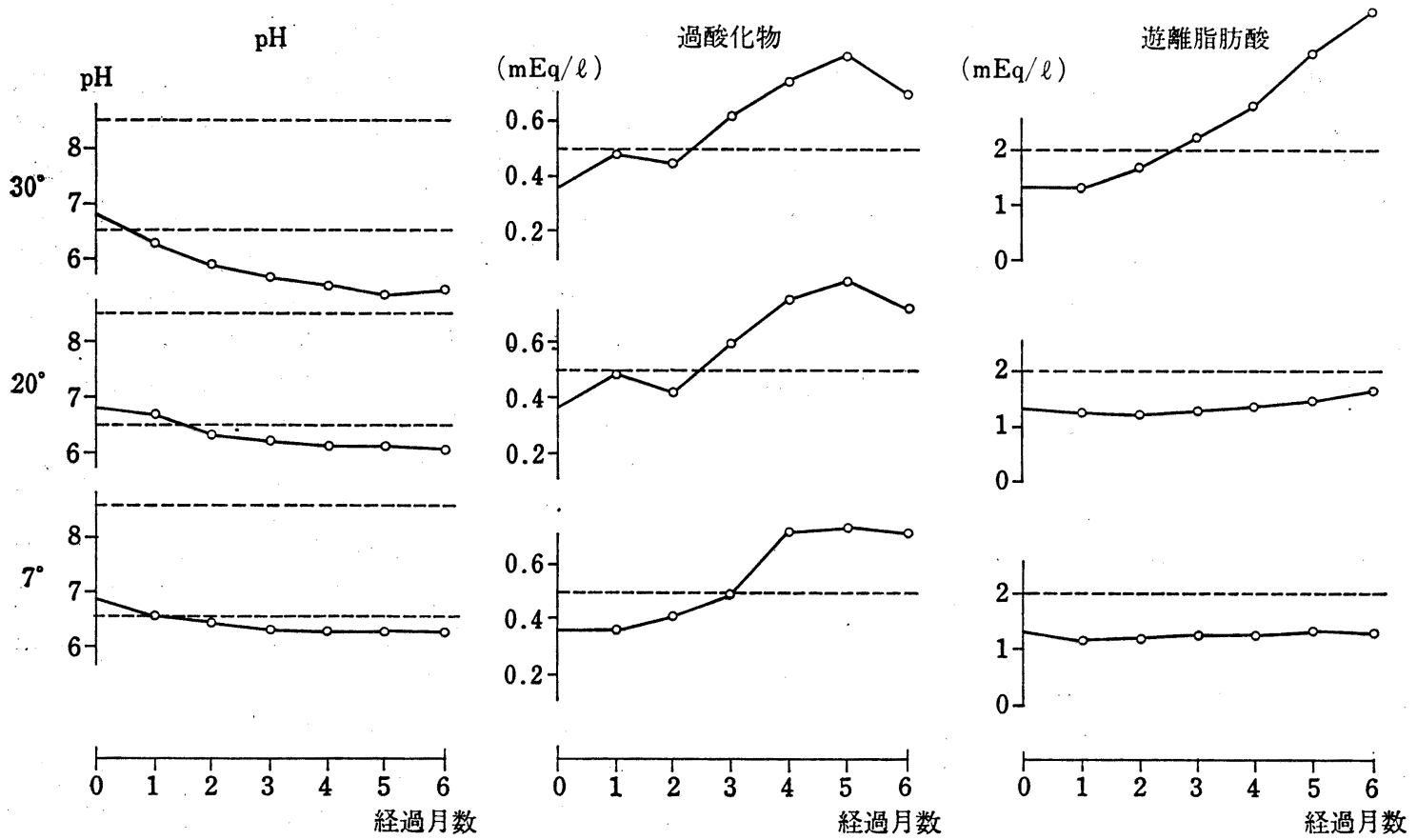

図 2. 各保存条件における武料 $\mathrm{B}$ の武験結果
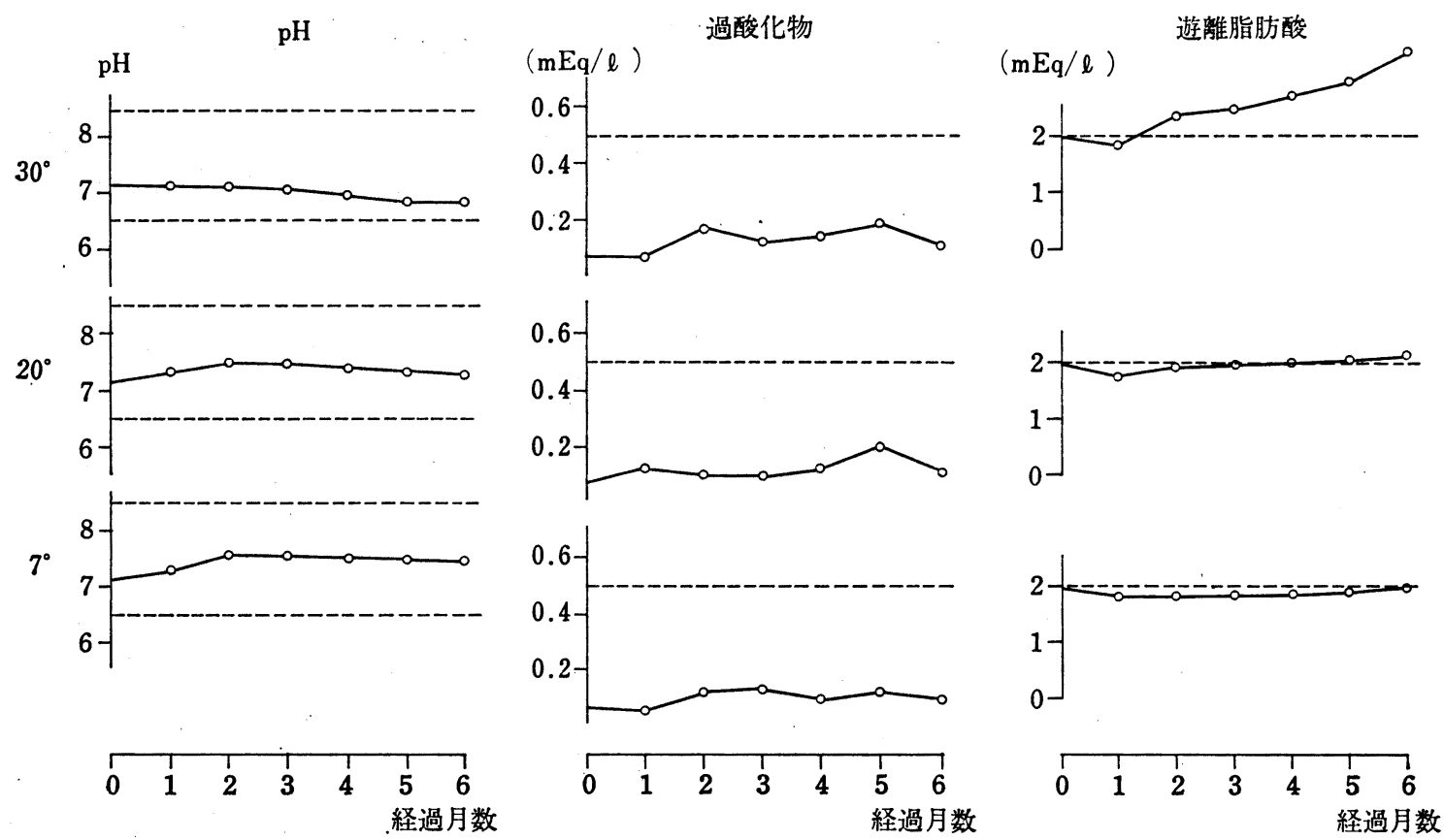

因 3. 各保存条件における試料 Cの試跧結果 


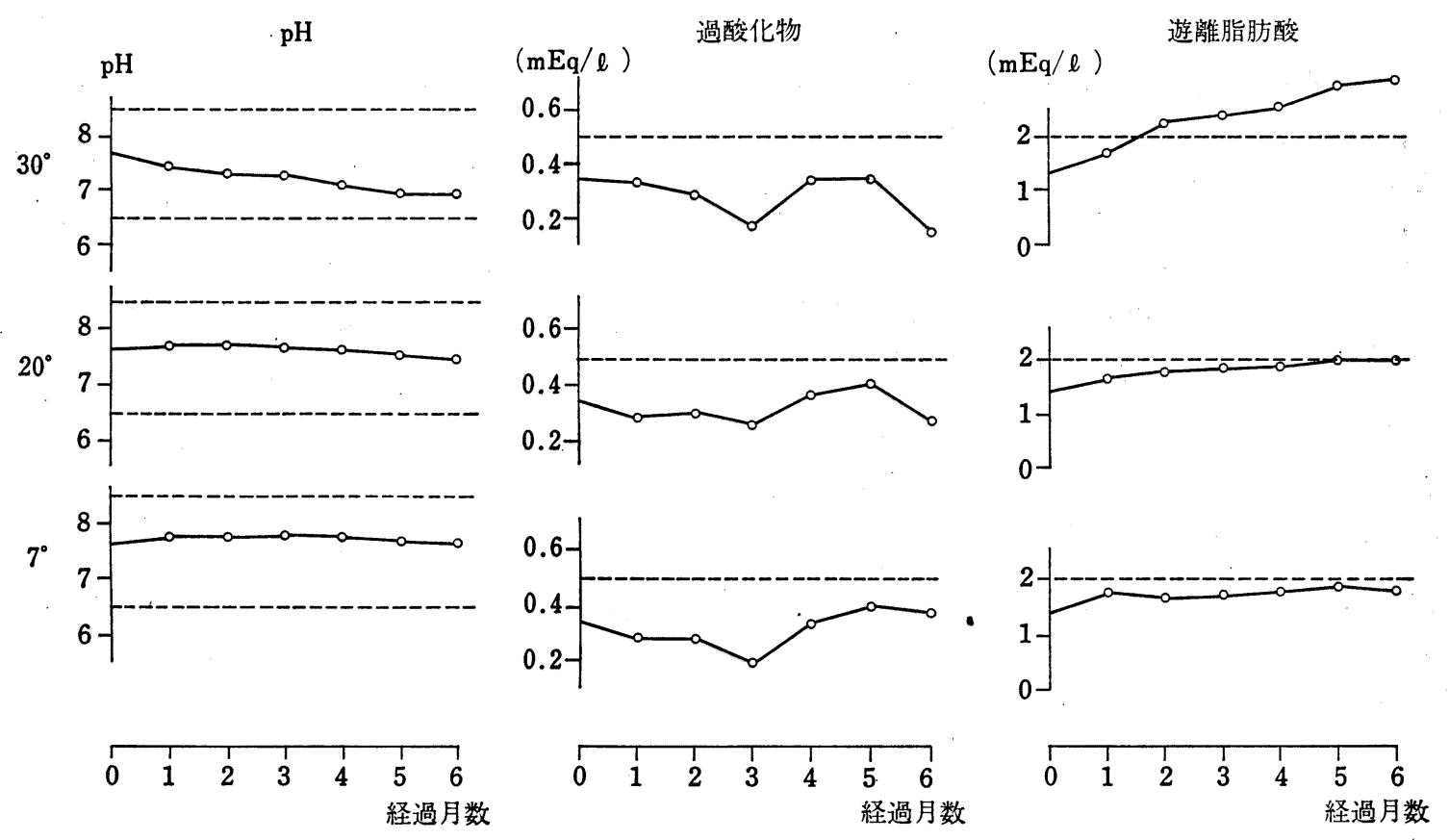

因 4. 各保存条件にわける試料 Dの試験結果

$20^{\circ} \mathrm{C}$ では变化はほとんどみられなかったが， $30^{\circ} \mathrm{C} の 2$ カ月目で規格範囲を超え， 6 カ月目では $3.09 \mathrm{mEq} / \mathrm{l}$ と なった.

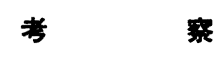

一般に, 脂肪の変質については主として空気酸化によ る酸敗現象が問題となる.この際, 不飽和脂肪酸におけ る過酸化物などの種々の物質の生成をみることが知られ ているが, 3) 本試験ではその中で過酸化物, 遊離脂肪酸, それに付随して变化する $\mathrm{pH}$ を測定することによりとの 程度を判定した.

Breinlich') の報告では, 大豆油と卵黄レシチンの組み 合わせが最す過酸化物の発生が少ないとしているが, 本 試験では製品 A と製品 B，C，Dの間に有意差はみられ なかった。

静注用脂肪乳剤は，酸化を防ぐ目的でバイアルびんの 空間が窒素固換されている. 製品 $\mathrm{A}, \mathrm{C}, \mathrm{D}$ では過酸 化物の增加がみられず，製品 Bでは增加がみられたが, 製剤の各社工程の違いなどすその一原因と考えられる。 また, 静注用脂肪乳㨈は, 乳化粒子が均一で毛細血管に つまらない大きさであることが必須であるが，その粒子 Ф大きさは一般に $1 \mu$ 以下であることが望ましいといわ れている.5,6) 佐藤 7 は， $4 \mu$ 以上の脂肪粒子による肺塞
栓を報告している．製品 $\mathrm{B} ， \mathrm{C} ， \mathrm{D}$ は $1 \mu$ 以上の粒子が みられたが， $3 \mu$ 以上の粒子は観察されず，肺塞栓など の副作用の発現は問題がないと考える. しかし日笠 ${ }^{8-10)}$ は，腸管に吸収された脂肪が循環系へ入る際のカイロミ クロンの大きさから， $0.5 \mu$ 以下であることを主張して いる.このことから考学ると, 粒子径のきわめて小さな 製品 Aが，静注用脂肪乳剤としてはより安全な乳化状態 であるといえる。

遊離脂肪酸は, 各試料之も規格值に近い比較的高い值 となったが，これは測定法として Dole の方法を用いた ために試料中のリン脂質の影響が現れ，このようになっ たと考えられる.しかし，明らかと遊離脂肪酸は各試料 共に $30^{\circ} \mathrm{C}$ 保存の場合增加し，経時変化がみられた。 4 試料のらち製品 Aは他飞比べて各試験結果でよい值を示 し, 粒子径も非常に小さく均一で, 乳化剤としては大豆 レシチンがすぐれているという結果となった。 しかし， Schuberth ${ }^{11)}$ は，異なる油脂, 乳化剤および溶媒の組合 わせ実験で，乳化剤では大豆りン脂質を用いた乳䠼が人 間に最す強い反応を示すことを報告しており，副作用軽 減のために大豆レシチンに水素を添加するなどす行われ ているが, 大豆リン脂質の副作用の問題は，今後の臨床 上の評価を待たねばならない問題であろう。 


\section{ま と め}

今回, 実験に用いた静注用脂肪乳剂 4 製品の保存温度 は, 2 $8^{\circ} \mathrm{C}, 25^{\circ} \mathrm{C}$ 以下および $15^{\circ} \mathrm{C}$ 以下（現在は室温）

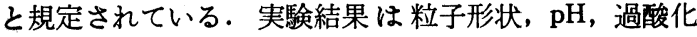
物, 遊離脂肪酸ともに, いずれの試験条件でも比較的安 定な製品もあったが，保存温度が高くなることと保存期 間が長くなることによって，一部の製品では遊離脂肪酸 の変化がみられ規格範囲を超えた。また， $\mathrm{pH}$, 過酸化物 の経時変化のみられる製品もあった。

静注用脂肪乳剂の保存条件は, 製剂内容, 製剂工程な どの違いにより必ずしも統一されるものではないが，高 温保存では品質の劣化がみられ，より高い安全性を必要 とする医薬品として問題があり，各社の規定する貯法は 参考とし，できるだけ冷所に保管することが望ましいと 考える.
文韵

1) Häkanson., I. : Acta Chem. Scand., 20 (8), 2267 (1966).

2) Dole, V. P. : J. Clin. Invest., 35, 150 (1956).

3）日本薬学会編：“衛生武臨法注解,” 1973, p.114.

4) Breinlich, J. : Die Krankenhaus Apotheke, 14, 11 (1964).

5) Frazer, A. C. \& Walsh, V. G. : J. Pharmacol. \& Exper. Therap., 67, 476 (1939).

6) Holt, L. E. Jr., Tidwell, H. C. \& Scott, T. F. M، : J. Pediat., 6, 151 (1935).

7) Sato, G. : Tohoku J. Exper. Med., 18, 120 (1931).

8）日笠頼則：最新医学, 13, 2278 (1958).

9）日笠頼則：最新医学, 13, 2586 (1958).

10）日笠頼則：最新医学, 13，2954 (1958).

11) Schuberth, O., Wretlind, A.: Acta Chir. Scand. Suppl., 278, 3 (1961).

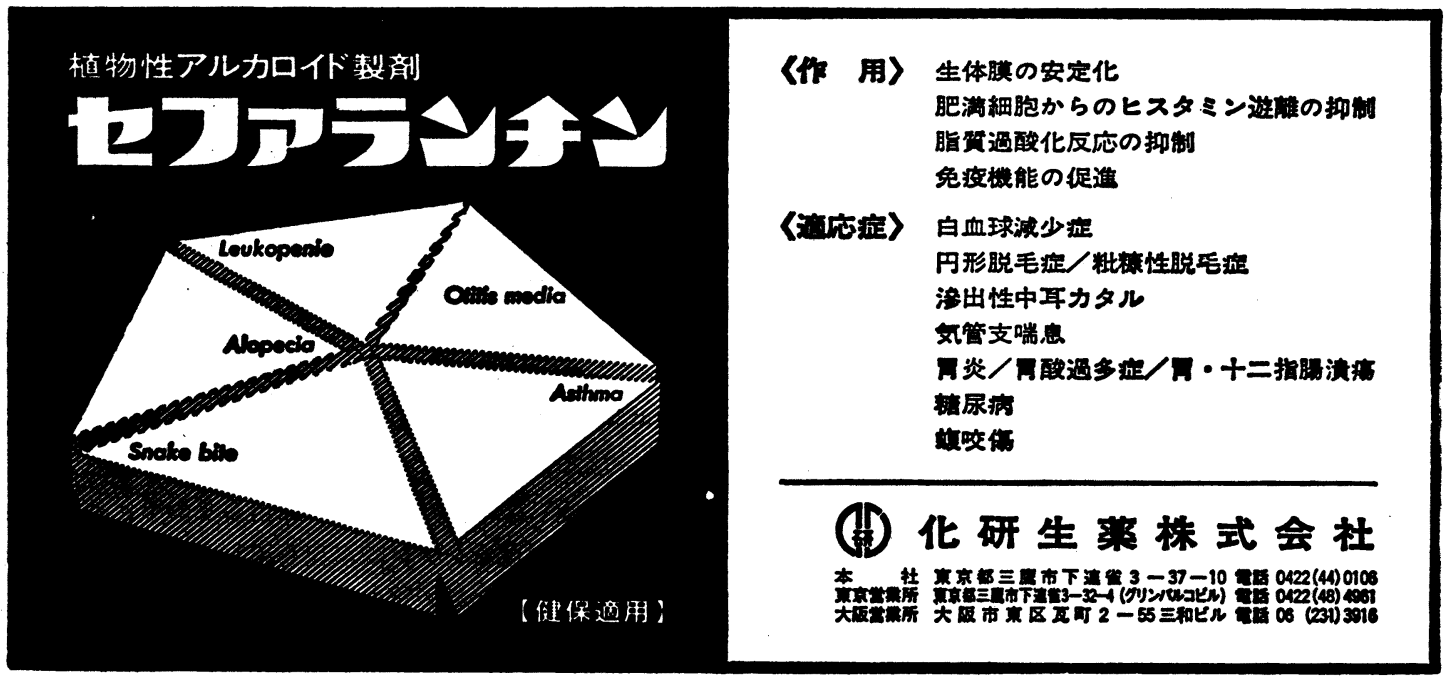

